\title{
A USUCAPIÃO EXTRAJUDICIAL E A ATUAÇÃO DO CARTÓRIO DE REGISTRO DE IMÓVEIS: UMA OPÇÃO PELA CELERIDADE OU MANUTENÇÃO DAS PRÁTICAS BUROCRÁTICAS?
}

\section{THE EXTRAJUDICIAL USUCAPTION AND THE PERFORMANCE OF THE REAL ESTATE REGISTRY: AN OPTION FOR CELERITY OR A CONCERVATION OF BUREAUCRATIC PRACTICES?}

\author{
Cláudia Franco Corrêa ${ }^{1}$ \\ Juliana Barcellos da Cunha e Menezes $^{2}$
}

\section{RESUMO}

O presente artigo tem como propósito a analise do impacto do Novo Código de Processo Civil na usucapião, concedendo especial atenção à nova modalidade, trazida com a inserção do artigo 1.071, que prevê a possibilidade de se pleitear a usucapião em cartório de registro de imóveis. Pontua-se ainda a fundamentação nos objetivos principais do novo código, dentre os quais destaca-se a busca pela celeridade. Propõe-se o afastamento do viés pessimista que conduz a desqualificação do instituto, para adoção de uma nova perspectiva, na qual, a ata notarial é sugerida como ferramenta facilitadora na efetivação do procedimento da usucapião.

Palavras-Chave: Usucapião; Ata Notarial; Efetividade; Celeridade; Extrajudicial.

\begin{abstract}
The purpose of this article is to analyze the impact of the New Code of Civil Procedure on a type of adverse acquisition, giving special attention the insertion of article 1.071, which provides for the possibility of claiming usucaption in a registry of titles concerning real estate. The legal provisions are also stated in the main objectives of the new code. It is proposed to move away from the pessimistic bias that leads to the disqualification of the institute, to adopt a new perspective, in which, the notarial deed is suggested as a facilitating tool in the implementation of the Usucaption.
\end{abstract}

Keywords: Usucaption; Notarial Deed; Effectiveness; Promptness; Extrajudicial.

\footnotetext{
${ }^{1}$ Mestre e Doutora em Direito pela Universidade Gama Filho - UGF/RJ, Rio de Janeiro (Brasil).Professora do PPGD da Universidade Veiga de Almeida (UVA) e Professora adjunta da UFRJ.

E-mail: francocorrea@oi.com.br

${ }^{2}$ Mestranda em Direito pela Universidade Veiga de Almeida - UVA, Rio de Janeiro (Brasil). E graduada em Direito pela Universidade Federal do Rio de Janeiro (UFRJ). E-mail: julianabarcellos@globo.com
} 


\section{INTRODUÇÃO}

O presente trabalho situa-se de modo geral na linha dos recentes estudos acerca das alterações trazidas pelo Novo Código de Processo Civil, que entrou em vigor no mês de março do corrente ano.

No entanto desde a apresentação de seu anteprojeto, tem-se observado consistentes discussões quanto à aplicação do novo código que, conforme determinação legal passou a reger não apenas as demandas ajuizadas após sua entrada em vigor, mais também aquelas já anteriormente em curso.

Em linhas gerais, o que está sendo, mormente, questionado é se as mudanças nos procedimentos, introduzidas pelo novo código, através da implementação de um rito único, que levou mais de 10 (dez) anos para ser finalizado e aprovado ${ }^{3}$, irão de fato cumprir os objetivos aos quais ele se propõe, de modo bastante resumido, trazer celeridade aos processos, conduzir sempre que possível a autocomposição dos conflitos e, não sendo esta viável, promover a produção de sentenças de qualidade.

O Novo Código, sem dúvida, fora elaborado tendo como um de seus principais objetivos, a solução de um problema histórico do direito brasileiro, a morosidade excessiva do procedimento. Muitos trabalhos acadêmicos e pesquisas publicadas demonstram o claro descontentamento da sociedade com a prestação jurisdicional, que além de onerosa demosntra-se demasiado lenta.

No âmbito do próprio judiciário tem-se reconhecido a necessidade imperiosa de uma justiça mais célere e eficaz, sob pena de o próprio processo funcionar como óbice na efetivação de direitos.

Nesse sentido afirma o Ministro Luiz Fux, presidente da Comissão de Juristas responsáveis pela elaboração do anteprojeto do novo código de processo civil, em carta endereçada ao Presidente do Congresso Nacional: "justiça retardada é justiça denegada”.

\footnotetext{
${ }^{3}$ A jornada dentro do Congresso Nacional objetivando a atualização do Código de Processo iniciou-se em 2005 , com o PL nº 6.025 e terminou em 2015 com a publicação deste.
} 
Nesta mesma linha, observa-se o posicionamento de Cappelletti e Garth, ao afirmarem que “a justiça que não cumpre suas funções dentro de 'um prazo razoável' é, para muitas pessoas, uma justiça inacessível” (CAPPELLETTI e GARTH, 1988, p.21).

De forma mais específica, o presente trabalho pretende explicitar a problemática gerada, com a entrada em vigor, através da Lei $n^{\circ}$ 13.105/2015 que instituiu o novo código de processo civil, da usucapião administrativa, também chamada de Usucapião Extrajudicial ou Usucapião em Cartório.

Nesse sentido, há que se situar que tal instituto deriva da tentativa do novo código de “desjudicializar" o acesso a declaração da propriedade pela usucapião e, para tal, valoriza a participação de outros órgãos na solução de litígios e a autocomposição de conflitos, como ferramentas que, se utilizadas de modo correto, isso é, mantendo o comprometimento com as garantias constitucionais, especialmente o contraditório e a ampla defesa, podem contribuir de modo decisivo para "desafogar" o judiciário, que restringiria sua atuação aos casos em que a tutela jurisdicional fosse, de fato, imprescindível.

Nesse aspecto a desjudicialização tem sido encarada por alguns autores como um ponto relevante na reforma do judiciário, uma vez que, ao retirar a sobrecarrega de processos, libera-se o magistrado para se ocupar de questões que efetivamente necessitem de sua atuação e, sendo assim, consequentemente, elevar-se-ia a qualidade das decisões judiciais ${ }^{4}$.

Nessa linha, Francisco Carlos Duarte sugere, já no ano de 2005, que seja estimulado um movimento de desjudicialização, através do qual se retire da esfera de competência dos tribunais os atos e procedimentos cuja administração possa ser transferida a outras entidades, salvaguardando assim o núcleo essencial da função jurisdicional. (DUARTE, 2005)

Entretanto, em que pese a legitima fundamentação sob a qual repousa a criação da Usucapião Extrajudicial, que objetiva conceber a propriedade de forma menos burocrática e

\footnotetext{
${ }^{4} \mathrm{O}$ processo de desjudicialização no Direito Brasileiro não é uma novidade trazida pela lei , já era possível notar indícios desse movimento anteriormente, por exemplo, através da edição dos seguintes dispositivos legais, citados em ordem cronológica. Lei $\mathrm{n}^{\circ} 8.560 / 92$ que trata o reconhecimento de paternidade perante os serviços de registro civil; Lei $\mathrm{n}^{\mathrm{o}} 8.951 / 1994$, criou o procedimento extrajudicial para a consignação em pagamento de obrigação em dinheiro; Lei ${ }^{\circ}$ 9.307, de 23 de setembro de 1996 regulamentou a Arbitragem; Lei no 9.514/97 rege os procedimentos de notificação do devedor e leilão extrajudicial nos contratos de alienação fiduciária; Lei $\mathrm{n}^{\circ}$ 10.931/2004, autoriza a retificação administrativa dos registros imobiliários;
} 
menos formal, nota-se que, mesmo antes de a nova modalidade de aquisição de domínio ter tido tempo hábil para ser utilizada, já tem gerado muita resistência entre os profissionais, inclusive, dentro da própria academia.

Tal resistência, sem dúvida, também encontra fundamento lógico, haja vista que, em primeira análise, não parece compreensível que toda a conhecida burocracia cartorária possa de algum modo, trazer celeridade e simplificar o procedimento da Usucapião, até então, tido como um dos mais dificultosos procedimentos especiais descritos pelo antigo código de processo civil.

Nesse sentido, de modo ainda mais restrito, o presente artigo não pretende trabalhar o processo de desjudicialização como um todo, mas concentrar-se especialmente nos questionamentos levantados acerca da Usucapião Extrajudicial, sob uma perspectiva um pouco mais otimista do que tem-se observado no meio jurídico.

Para tal, utilizar-se-á da apresentação da Ata Notarial como instrumento facilitador na efetivação desta nova forma de procedimentalizar a usucapião, sustentando a hipótese de que a correta utilização desta poderá contribuir de forma decisiva para garantir o sucesso da nova ferramenta.

Neste contexto, busca-se ainda perquirir se a usucapião extrajudicial processada no registro de imóveis seria uma opção pela celeridade ou, ao contrário, se mantém com as mesmas racionalidades burocráticas e impeditivas do processamento da usucapião judicial, observando que tais cartórios são verdadeiros locus de burocracias.

Não seria, portanto, uma opção mais viável a escolha de processamento junto ao cartório de notas, deixando o registro de imóveis com a sua atuação de práxis, circulada no registro em si?

Do ponto de vista metodológico, o presente trabalho é resultado de uma pesquisa bibliográfica prévia, realizada na melhor doutrina e também de uma pesquisa de campo, in loco, através da qual observamos a atuação de um dos maiores cartórios de ofício de notas da cidade do Rio de Janeiro para análise pontual da feitura das atas notariais, bem como 
investigação em um Cartório de registro de imóveis, a fim de, empiricamente, pesquisarmos a eficácia das alterações trazidas pelos novos ventos do atual Código de Processo Civil.

Utilizando essa dupla abordagem, consideramos que já seria possível elencar dilemas e perspectivas consistentes que, possivelmente, se consolidarão com a efetiva utilização do novo dispositivo legal, pontuando seus aspectos mais controversos e demonstrando possibilidades viáveis para sua efetivação.

\section{CONSIDERAÇÕES SOBRE A USUCAPIÃO EXTRAJUDICIAL INSTITUÍDA PELA LEI No 13.105/2015: CRÍTICAS E QUESTIONAMENTOS ACERCA DO NOVO INSTITUTO.}

Antes de adentrar a Usucapião Extrajudicial propriamente dita, cabe pontuar algumas nuanças em relação à ação de usucapião em geral.

Em primeiro lugar, vale lembrar que independente da modalidade escolhida, cujos prazos e requisitos variam de acordo com o disposto no Código Civil de 2002, trata-se de ação cuja sentença proferida tem natureza meramente declaratória. Desta forma, aduz-se que cabe ao magistrado de forma objetiva, uma vez comprovado o preenchimento dos requisitos e o decurso do lapso temporal previsto em lei, declarar a aquisição da propriedade pela via da usucapião.

Em razão desta natureza, a doutrina entende majoritariamente que a usucapião é forma de prescrição aquisitiva, a medida que consolida, ao mesmo tempo, a aquisição e a perda de um direito com base no decurso do tempo.

Alexandre de Freitas Câmara pontua que "trata-se de sentença meramente declaratória, porque a sentença de procedência do pedido em ação de usucapião não constitui o direito de propriedade, mas tão somente reconhece um domínio pré-existente" (CÂMARA, 2009, 379-380).

Em raciocínio diretamente oposto, embora fortemente minoritária, aproveitamos a oportunidade para pontuar a posição dos juristas Caio Mário da Silva Pereira, Cristiano Chaves e Nelson Rosenvald, que se opõe ao tratamento da usucapião como forma de 
prescrição aquisitiva; considerando que, diferente do que ocorre com as prescrições, não basta o simples decurso do tempo para ensejar a ocorrência da usucapião. De modo bastante particular, para que haja a aquisição da propriedade pela via da usucapião, o fator tempo deve somar-se a uma conduta positiva de outrem, consubstanciada na posse com anumis domini.

Dito isso, ressaltamos que para a discussão a que nos propomos no presente paper, vamos afastar esse imbróglio terminológico e centrar atenção na já mencionada natureza indiscutivelmente declaratória da sentença das ações de usucapião.

Tal natureza nos permite avançar no raciocínio de que para garantir a segurança jurídica da decisão, basta que haja o reconhecimento inequívoco do preenchimento dos requisitos e do decurso do tempo, declarado por autoridade competente, dotada de fé pública e posteriormente registrada para que tenha oponibilidade erga omnes.

Muito possivelmente essa foi a linha de raciocínio adotada pelo legislador quando conferiu aos cartórios de registros de imóveis a possibilidade de declarar a usucapião, conforme se depreende da leitura do artigo 1.071 do Novo Código de Processo Civil, que acresce à Lei dos Registros Públicos (Lei n 6.015/73) o artigo 216-A, in verbis.

Sem prejuízo da via jurisdicional, é admitido o pedido de reconhecimento extrajudicial de usucapião, que será processado diretamente perante o cartório do registro de imóveis da comarca em que estiver situado o imóvel usucapiendo, a requerimento do interessado, representado por advogado, instruído com $[\ldots]$

O parágrafo segundo deste mesmo artigo, prevê a notificação do proprietário do bem pelo registrador, para que este manifeste seu consentimento expresso no prazo de 15 (quinze) dias, devendo interpretar seu silencio como discordância.

Tal dispositivo, concluímos, apenas reintera a valorização pelo legislador da natureza declaratória da usucapião, objetivando facilitar a regularização da propriedade, uma vez que considera factível que o proprietário responda a notificação cartorária, de modo a reconhecer a perda da propriedade. 
Neste raciocínio, a primeira vista, causa a nítida impressão de que o instituto em comento já "nasceu” fadado ao insucesso, pois não parece razoável considerar que qualquer proprietário anuirá com a perda de seu próprio imóvel.

De fato, não se pode negar o fundamento lógico contido nesse pensamento, e certamente a concordância expressa do titular de direito real irá, em princípio, obstacularizar a efetivação da usucapião em cartório.

Porém, se adotarmos uma perspectiva mais futura, a facilitação da usucapião e, principalmente, a popularização da via extrajudicial, podem ocasionar uma mudança de paradigma, a medida que, restando evidenciado o direito, a discordância do detentor do direito real só acarretará prejuízos a ele próprio, já que até que seja reconhecida a usucapião, terá que arcar com todos os custos inerentes a propriedade e ao processo, mesmo sem usufruir da posse do bem.

Em que pese em primeira analise tal alteração não pareça verossímil, importante pontuar que dinâmica parecida já ocorreu no direito brasileiro anteriormente; no caso do divorcio litigioso.

Em síntese, era muito comum que um dos cônjuges, que não concordava com o divórcio, oferecesse todo tipo de dificuldade para dissolução do vínculo matrimonial, porém com o passar dos anos, o divórcio vem sendo cada vez mais compreendido como um direito potestativo, podendo inclusive ser realizado em cartório, e os cônjuges descontentes tem cada vez mais percebido que protelar a concretização do divórcio não os trará qualquer benefício.

Superada essa dificuldade de ordem subjetiva, passemos a analise dos requisitos do procedimento.

Nesse aspecto, a necessidade da intimação da fazenda pública da união, do estado, e do município, foi mantida pelo novo código, também na via administrativa, por força do parágrafo $3^{\circ}$ do art. 1.071 do NCPC; a diferença para o processo judicial é que, no âmbito dos cartórios, deve ser efetivada pessoalmente, por intermédio do oficial de registro de títulos e documentos, ou pelo correio com aviso de recebimento. 
O prazo para manifestação também permanece igual, 15 (quinze) dias ${ }^{5}$, devendo ainda ser providenciada pelo oficial a publicação de edital em jornal de grande circulação, onde houver, para a ciência de terceiros eventualmente interessados, aos quais foi concedido igual prazo para manifestação.

A maior diferença encontrada no novo código nesse ponto diz respeito à necessidade de intervenção do Ministério Público, uma vez que não há determinação expressa de notificação deste órgão nos casos da Usucapião Extrajudicial. Portanto, com base no texto normativo, consideramos, a priori, que legislador dispensou a participação do Ministério Público.

O parágrafo $5^{\circ}$ do art. 1.071 prevê a possibilidade de suscitação de dúvida, nesse caso o que pode ocorrer é um requerimento ao oficial registrador que dará inicio a um processo que será encaminhado ao juiz da vara de registros públicos, que deve atuar para sanar eventuais dúvidas. Esse procedimento está detalhadamente descrito no art. 198 da Lei de Registros Públicos. In verbis.

Havendo exigência a ser satisfeita, o oficial indicá-la-á por escrito. Não se conformando o apresentante com a exigência do oficial, ou não a podendo satisfazer, será o título, a seu requerimento e com a declaração de dúvida, remetido ao juízo competente para dirimi-la, obedecendo-se ao seguinte:

I - no protocolo, anotará o oficial, à margem da prenotação, a ocorrência da dúvida;

II - após certificar, no título, a prenotação e a suscitação da dúvida, rubricará o oficial todas as suas folhas;

III - em seguida, o oficial dará ciência dos termos da dúvida ao apresentante, fornecendo-lhe cópia da suscitação e notificando-o para impugná-la, perante o juízo competente, no prazo de 15 (quinze) dias;

\footnotetext{
${ }^{5}$ Seguindo o entendimento trazido pelo novo código com relação a contagem de prazos processuais, entendemos que este prazo também deve ser contado apenas em dias úteis, excluído, portanto, os feriados e finais de semana. Art.
} 
IV - certificado o cumprimento do disposto no item anterior, remeter-se-ão ao juízo competente, mediante carga, as razões da dúvida, acompanhadas do título.

A admissão dessa possibilidade pelo legislador tem sido um dos pontos mais criticados pelos operadores do direito; a quem diga que a inclusão do referido parágrafo configurará um serio óbice à eficácia do instituto, a medida que retornará com o processo para o judiciário, comprometendo, na visão de muitos, a celeridade.

De fato, nesse aspecto, temos que reconhecer que devolver a questão ao judiciário pode realmente prolongar o procedimento, de modo que seus principais fundamentos, em especial a celeridade, restem seriamente comprometidos.

Porém há que se considerar também, que a possibilidade de levar eventuais dúvidas ao judiciário, por certo, vai encorajar os advogados e operadores do direito a aventurarem-se no uso do novo instituto.

Este encorajamento, ao que nos parece, também faz parte do objetivo do legislador, que garantiu de imediato, no caput do artigo 216-A da Lei 6.015/73, a possibilidade de uso da via administrativa, sem prejuízo de posterior utilização da via judicial, in verbis.

Art. 216-A. Sem prejuízo da via jurisdicional, é admitido o pedido de reconhecimento extrajudicial de usucapião, que será processado diretamente perante o cartório do registro de imóveis da comarca em que estiver situado o imóvel usucapiendo, a requerimento do interessado, representado por advogado, instruído com: (Incluído pela Lei nº 13.105, de 2015).

\section{O EXERCÍCIO DA ATIVIDADE NOTARIAL E REGISTRAL NO BRASIL, UMA ANÁLISE DA NATUREZA JURÍDICA E DA RESPONSABILIDADE CIVIL.}

Antes de adentrarmos ao ponto principal do presente artigo, qual seja: a apresentação da ata notarial como instrumento apto a auxiliar e conceder eficácia e celeridade a usucapião extrajudicial, convém tecer breves considerações acerca da atividade notarial e registral no Brasil. 
A atividade em comento está prevista no artigo 236 da Constituição Federal e, de acordo com a corrente doutrinária majoritária os notários e registradores exercem função pública por delegação. Esse entendimento é, inclusive, corroborado na Lei 8.935/94, conhecida como Lei dos Cartórios, em seu artigo terceiro que dispõe: "Notário, ou tabelião, e oficial de registro, ou registrador, são profissionais do direito, dotados de fé pública, a quem é delegado o exercício da atividade notarial e de registro".

Não obstante o caráter reconhecidamente privado do serviço, por tratar-se de função pública de suma importância à administração estatal, a Constituição Federal previu, no parágrafo $3^{\circ}$ do artigo 236 a necessidade de concurso público para ingresso na atividade, senão vejamos:

§3. O ingresso na atividade notarial e de registro depende de concurso público de provas e títulos, não se permitindo que qualquer serventia fique vaga, sem abertura de concurso de provimento ou de remoção, por mais de seis meses.

Deste modo, concluímos que não se pode pensar a atividade notarial como função tipicamente privada, apta a ser exercida livremente por qualquer cidadão no âmbito da livre iniciativa e da livre concorrência. Muito pelo contrário, por força constitucional essa atividade é delegada pelo estado que detém sua titularidade, afinal, como sabemos, só pode delegar uma atividade, aquele cuja titularidade desta possui.

Assim sendo, concluímos que se trata de função pública, delegada pela Constituição à iniciativa privada, cujo exercício é regulamentado por lei e o ingresso condicionado a concurso público de provas e títulos, como nos ensina Celso Antonio Bandeira de Mello.

Não se deve confundir a titularidade do serviço com a titularidade da prestação do serviço. Uma e outra são realidades jurídicas visceralmente distintas. O fato de o Estado ser titular de serviços públicos, ou seja, de ser o sujeito que detém senhoria sobre eles (a qual, de resto é, antes de tudo, um dever em relação aos serviços que a Constituição ou as leis puseram ou venham a por seu cargo) não significa que deva obrigatoriamente prestá-los por si ou por criatura 
sua quando detenha a titularidade exclusiva do serviço. Assim, tanto poderá prestá-los por si mesmo como poderá promover-lhes a prestação conferindo a entidades estranhas ao seu aparelhamento administrativo (particulares e outras pessoas de direito público interno ou da administração indireta delas) titulação para que os desempenhem, isto é para que os prestem segundo os termos e condições que fixe. (MELLO: 2007 p.659 e 660)

A questão principal que diverge a doutrina administrativista, já há alguns anos, gira em torno de saber se os notários e registradores são de fato servidores públicos. Nesse aspecto muitos são os posicionamentos encontrados, porém consideramos que o cerne da questão é meramente terminológico e não caberia na discussão proposta neste trabalho, porém, a título de ilustração, ressalta-se o posicionamento de Maria Helena Diniz.

O oficial imobiliário e seus funcionários são servidores públicos, subordinados a órgãos estatais, integrados ao Executivo e Judiciário. O oficial de registro imobiliário não é um servidor público ordinário; é um técnico incumbido de registrar a aquisição de um imóvel ou a sua oneração, constituindo, com o assento, um direito real em favor de alguém. A tecnicidade de sua função requer qualidade de serviços prestados. O oficial titular do Cartório é servidor público, tendo autonomia administrativa, mas não é remunerado pelo Estado, e sim, pelos interessados no registro, pois terá direito, a título de remuneração, a emolumentos, fixado por órgão competente, pelos atos praticados. O Poder Público não arcará com o ônus dos serviços do Registro Imobiliário. Embora exerça função pública em interesse próprio, não estando vinculado ao Estado por uma relação hierárquica, ele se subordina aos critérios estatais quanto à fiscalização, disciplina e punição dos atos por ele praticados, oficializados ou privatizados; portanto, o serventuário é um servidor público (DINIZ: 2006. p. 619 e 620$)$

Por outro lado, Hely Lopes Meirelles os classifica como pertencentes à categoria dos "agentes delegados, formada por particulares que recebem a incumbência de determinada 
atividade, obra ou serviço público, por sua conta e risco, mas segundo normas do Estado e sob permanente fiscalização do delegante" (MEIRELLES: 2006. p 80).

No entanto, citada a divergência acerca da natureza jurídica da atividade registral, pontuamos que esta, em nada influencia na questão da responsabilidade civil atribuída aos notários e registradores, Esta, já razoavelmente pacificada, encontra previsão no artigo 22 da Lei dos Cartórios, que em primeira análise lhes atribui responsabilidade objetiva pelos danos causados, a medida que dispõe o seguinte: “Os notários e oficiais de registro responderão pelos danos que eles e seus prepostos causem a terceiros, na prática de atos próprios da serventia, assegurado aos primeiros direito de regresso no caso de dolo ou culpa dos prepostos."

Porém, em interpretação conjunta com o disposto na Constituição Federal, conclui-se que o Estado deva responder objetivamente pelos danos causados pelos notários e registradores, haja vista que estes exercem função pública por delegação, sem prejuízo, por obvio, da responsabilidade destes por atos praticados por seus prepostos e funcionários. Esse foi o entendimento do Supremo Tribunal Federal no julgamento do Recurso Extraordinário 209.354 do Paraná, senão vejamos:

RESPONSABILIDADE CIVIL DO ESTADO - ATO DE TABELIÃO. PROCURAÇÃO INAUTÊNTICA, PORQUE OBJETO DE FRAUDE NA DOCUMENTAÇÃO APRESENTADA QUANDO DA SUA LAVRATURA. PREJUÍZO A TERCEIRO QUE TEVE ANULADO O ATO JURÍDICO REFERENTE À AQUISIÇÃO DE TERRAS QUE FEZ ATRAVÉS DA REFERIDA PROCURAÇÃO. RESPONSABILIDADE DO ESTADO DO PARANÁ POR ATOS PRATICADOS PELOS SEUS AGENTES (ART. 37, N. XXI,§ 6º DA CONSTITUIÇÃO FEDERAL). SE O TABELIÃO, EMBORA NÃO PERCEBENDO DOS COFRES PÚBLICOS, É FUNCIONÁRIO PÚBLICO PARA EFEITO DE RESPONSABILIDADE CIVIL, INDISCUTÍVEL QUE AO ESTADO 


\section{INCUMBE RESSARCIR OS DANOS QUE TAL FUNCIONÁRIO} CAUSAR A TERCEIRO. REEXAME NECESSÁRIO IMPROVIDO (... $)^{6}$.

Apesar das divergências que ainda restam com relação ao tema, uma coisa é certa, a atividade notarial e registral praticada nos parâmetros determinados em lei, concede robusta segurança a seus usuários, que além da garantia da fé pública atribuída ao oficial registrador, podem ainda contar com a responsabilidade objetiva do estado no caso de eventuais danos.

\section{A CONSTRUÇÃO E ELABORAÇÃO DA PROBLEMÁTICA, QUE CONDUZIU A BUSCA POR UM NOVO ENTENDIMENTO.}

A problemática sob a qual repousa o presente paper é bastante recente, conforme narrado na introdução, iniciou-se com a divulgação do anteprojeto do novo código de processo civil. Desde então, muito tem sido discutido acerca da real eficácia prática do instituto da usucapião administrativa e seus dispositivos, o que nos levou a percepção de uma perspectiva geral bastante pessimista com relação à eficácia do referido instituto, a qual nós, inclusive, em um primeiro momento, partilhamos.

Ocorre que de igual modo, o procedimento especial das ações de usucapião descrito no antigo Código de Processo Civil de 1973, durante muitos anos foi objeto de crítica no ambiente acadêmico, de modo que é possível encontrar uma série de artigos científicos tratando de suas ineficiências.

A elaboração do novo dispositivo trazia, desde seu projeto inicial, a esperança de uma mudança substancial no tocante ao procedimento da ação de usucapião, com o objetivo de tornar mais efetivo o acesso ao direito em suas diversas modalidades, tendo por fundamento legal o destaque dado pela constituição de 1988 à função social da propriedade como principio limitador do próprio direito de propriedade.

Desta forma, optamos por nos basear em críticas formuladas pela doutrina, bem como no que supomos ter sido o entendimento do legislador na criação do novo código de processo civil, para enxergar e propor possíveis soluções legais aos entraves ora levantados,

${ }^{6}$ STF - RE: 229974 PR, Relator: Min. NÉRI DA SILVEIRA Data de Julgamento: 28/09/2001, Data de Publicação: DJ 12/11/2001. 
adotando uma perspectiva mais otimista, pautada na proposta de utilização de uma ferramenta que, a nosso ver, pode contribuir para uma melhor utilização do tão esperado instituto da usucapião administrativa, viabilizando a concretização, não apenas dos objetivos individuais perseguidos no caso concreto, mas também e, principalmente, do instituto enquanto parte integrante dos objetivos traçados pela lei 13.105/15 que, em consonância com os valores constitucionais visa, dentre outras coisas, dinamizar o acesso a propriedade em seus muitos aspectos.

\section{A ATA NOTARIAL COMO FERRAMENTA FACILITADORA PARA EFETIVAÇÃO DA USUCAPIÃO EXTRAJUDICIAL.}

Passamos agora a tratar da Ata Notarial, propriamente dita, já que esta figura como um dos destaques do novo código, que a concede especial tratamento, passando a reconhecêla expressamente como meio típico de prova.

Nesse influxo, pontua-se que a utilização da ata confeccionada em cartório como conteúdo probatório processual já era uma possibilidade, que eventualmente era utilizada pelos advogados. Porém, sem dúvida, o fato de o legislador ter optado por menciona-la expressamente acabou por revesti-la de maior robustez.

Nesse novo cenário, resultado da soma da fé pública atribuída aos registradores, com a previsão expressa da ata como meio de prova, a importância da certificação cartorária, acreditamos, crescerá bastante. E, apesar da manifesta resistência de parte dos juristas à burocracia atribuída aos registros de notas, é preciso reconhecer que estes podem funcionar como alternativa a morosidade excessiva do judiciário, podendo, inclusive, produzir fortes ferramentas de auxilio, para acelerar a instrução probatória do processo judicial promovendo o amadurecimento da causa de forma segura.

Contudo nosso interesse específico não está centrado propriamente em tratar da utilização da ata notarial como meio de prova nos processos judiciais, embora reconheçamos o grande avanço que isso representa no sentido de se conseguir uma razoável duração dos processos. Nosso empenho neste artigo é demonstrar o papel fundamental que esta poderá assumir no contexto da usucapião extrajudicial, funcionando como solução trazida no texto do próprio código, para os entraves advindos da aplicabilidade prática da nova ferramenta. 
Em um rápido passeio pelo universo dos que criticam a inclusão da usucapião extrajudicial no âmbito do procedimento civil, notamos que existem duas que podemos chamar de principais, a medida que se manifestam de forma reiterada, são elas:

a) Os Registros Gerais de Imóveis jamais poderão contribuir para a celeridade, por serem altamente burocráticos, de modo que farão muitas exigências que obstarão o procedimento.

b) Ao retirar o procedimento do âmbito do judiciário, aumenta-se consideravelmente o risco de fraude.

Por óbvio esses argumentos tem bons fundamentos, e configuram de fato grandes riscos de insucesso do procedimento. Porém, o que defendemos nesse trabalho é a adoção de uma postura protagonista na solução dos entraves postos. Neste caso especifico, é plausível vislumbrar na utilização da ata notarial, uma possibilidade de alcançar bons resultados no caminho da busca pela plena eficácia da usucapião extrajudicial.

Atualmente, faz-se necessário observar a nova roupagem que fora atribuída a ata notarial, enquanto ferramenta apta a certificar fatos com fé publica e oponibilidade erga omnes, servindo como prova plena.

Para atuarmos na solução do primeiro problema apresentado, sugerimos a elaboração da ata de forma muito mais abrangente do que comumente praticado na vigência do antigo código, facilitando assim o trabalho do juiz e do registrador. Na prática seria como "pular" muitas etapas que, sabemos, consomem muito tempo e adentrar no âmbito judicial ou cartorário, já com as várias exigências legais cumpridas, comprovadas e certificadas.

De certo, o sucesso da proposta está umbilicalmente relacionado ao esforço conjunto de advogados e notários; pois caberia a eles, com base na analise dos documentos trazidos e no depoimento das partes, certificar e comprovar: o enquadramento do caso em uma das espécies de usucapião previstas em lei, o tamanho do imóvel, a ocorrência de causas que impeçam a prescrição, a notificação da União, do Estado e do Município, a existência de posse ad usucapionem, a prévia tentativa de mediação e todos os vários outros requisitos previstos em lei. 
Embora elaborada de forma mais ampla, a ata notarial serviria apenas para certificar o cumprimento de todos os requisitos indispensáveis à declaração da usucapião, de forma objetiva, com base na analise de documentos apresentados, não extrapolando em nenhuma hipótese a competência atribuída aos notários, por força dos artigos $6^{\circ}$ e $7^{\circ}$ da Lei 8.935/94. ${ }^{7}$

Em relação ao segundo problema apresentado, ressaltamos que não o consideramos de fato um entrave, pois não parece razoável crer em qualquer segurança, advinda da via judicial, que justifique a exclusão do procedimento administrativo, principalmente se considerarmos que, ao contrario dos magistrados, a responsabilidade do tabelião é objetiva em caso de eventuais danos, salvaguardando, ainda, a responsabilidade também objetiva do estado. (conforme demonstrado no item 2) .

\section{CONSIDERAÇÕES ACERCA DO PARECER EMITIDO PELA CORREGEDORIA PARA PROCESSAMENTO DA USUCAPIÃO EM CARTÓRIO.}

Após a entrada em vigor do novo código, assim como toda a comunidade jurídica, os cartórios de notas não detinham qualquer expertise na confecção de atas com a finalidade de usucapião, razão pela qual, em um primeiro momento, a maioria negou-se a efetuar o registro.

Com o objetivo de auxiliar os cartórios e efetivar a disposição legal, a corregedoria nacional de justiça emitiu um parecer, a fim de esclarecer as etapas do procedimento e auxiliar os escrivães.

O parecer em comento esclarece antigas controvérsias já pacificadas nos tribunais superiores e viabiliza o registro da usucapião em cartório, mesmo nos casos mais complexos, como por exemplo, a usucapião em loteamento irregular e a usucapião de unidade autônoma em condomínio edilício. No primeiro caso, o parecer claramente pontua que não há qualquer

\footnotetext{
7 Art. $6^{\circ}$ Aos notários compete: I - formalizar juridicamente a vontade das partes; II - intervir nos atos e negócios jurídicos a que as partes devam ou queiram dar forma legal ou autenticidade, autorizando a redação ou redigindo os instrumentos adequados, conservando os originais e expedindo cópias fidedignas de seu conteúdo; III - autenticar fatos.

Art. $7^{\circ}$ Aos tabeliães de notas compete com exclusividade: I - lavrar escrituras e procurações, públicas; II lavrar testamentos públicos e aprovar os cerrados; III - lavrar atas notariais; IV - reconhecer firmas; V autenticar cópias. Parágrafo único. É facultado aos tabeliães de notas realizar todas as gestões e diligências necessárias ou convenientes ao preparo dos atos notariais, requerendo o que couber, sem ônus maiores que os emolumentos devidos pelo ato.
} 
óbice à aquisição, advindo da irregularidade do loteamento. Já na segunda situação, a corregedoria esclarece que a citação dos confinantes, em condomínio edilício, pode ser realizada na pessoa do síndico.

Entretanto, também é possível identificar nesse parecer, eminentemente técnico, algumas incongruências com os dispositivos legais e com a própria natureza da usucapião, como, por exemplo, no parágrafo $4^{\circ}$ (quarto) do artigo $5^{\circ}$ (quinto), que dispõe o seguinte.

$\S 4^{\circ}$. A existência de ônus real ou de gravame na matrícula do imóvel usucapiendo não impede o reconhecimento extrajudicial de usucapião, hipótese em que o título de propriedade será registrado respeitando-se aqueles direitos, ressalvado o cancelamento mediante anuência expressa do respectivo $\underline{\text { titular de tais direitos. (grifo nosso) }}$

É fato que tal determinação viola característica fundamental da usucapião, que é forma originária de propriedade, de modo que se extrai da própria natureza do instituto que a propriedade adquirida por esta via não carrega nenhum gravame anteriormente fixado, devendo, razão pela qual deve, inclusive, ser aberta nova matrícula, o que também é retificado pelo parecer em comento, em seu artigo décimo parágrafo terceiro, que dispõe: "Na hipótese de o imóvel usucapiendo encontrar-se matriculado e o pedido referir-se à totalidade do bem, o registro do reconhecimento extrajudicial de usucapião será feito na própria matrícula existente."

Deste modo, observa-se uma insegurança com relação à aplicação do instituto que abrange todos os atores envolvidos no procedimento e justifica a já conhecida tentativa de burocratizar para conferir segurança ao método, o que, neste caso, representa um contrario senso. $^{8}$

\section{CONCLUSÃO.}

Por fim, destacamos que qualquer conclusão que elaboremos para o presente paper, de certo representará uma constatação obtida através da análise de um resultado parcial, advindo de uma investigação prévia, haja vista a ausência do decurso de lapso temporal

${ }^{8}$ Cabe esclarecer que o mencionado parecer foi submetido a consulta pública de modo que ainda deverá sofrer alterações. 
razoável, que nos permita de fato avaliar de modo consistente a problemática surgida com a aplicação da usucapião extrajudicial, dada a recente entrada em vigor do novo código.

Porém, com base nos dados extraídos da pesquisa e apresentados nesse artigo, sugerimos que a usucapião, dada sua natureza declaratória, poderá funcionar bem em um atual contexto de "desjudicialização", simplificando o acesso à escritura de propriedade, contribuindo de forma efetiva para um processo de regularização fundiária.

Deste modo a ampla utilização do instituto trará como contribuição social a regularização da propriedade, que trás consigo todos os seus direitos e deveres, transformando situações "de fato" em situações "de direito", tal como já ocorreu com a instituição dos procedimentos extrajudiciais de divórcio e inventário.

Sugerimos ainda que adoção da ata notarial de forma plena e eficaz por notários e advogados, pode funcionar de modo bastante eficiente e garantir o sucesso da declaração de usucapião em cartório a medida que o legislador de modo expresso trouxe robustez e segurança jurídica a ela, dedicando um título no novo código apenas para trata-la.

Isto posto, sabemos que, embora burocráticos, os procedimentos realizados no âmbito de atuação dos cartórios são muito mais céleres que a grande maioria dos procedimentos judiciais e, no caso específico da usucapião, que necessita de um vasto numero de diligencias e manifestações de muitos órgãos e pessoas para sua configuração, a morosidade era especialmente criticada.

Pontua-se ainda que a utilização da via cartorária para elaboração da ata notarial não necessariamente precisa funcionar como alternativa ao procedimento jurisdicional, pode também contribuir para a celeridade deste, certificando com segurança o cumprimento das diligencias exigidas pelo legislador e retirando do judiciário não o poder decisório que por fim poderá declarar a aquisição originária da propriedade, mas o trabalho procedimental o qual sobrecarregava ainda mais as serventias judiciais e retardava o andamento do processo.

A possibilidade optar por essa utilização conjunta das vias administrativa e judicial, da origem a um procedimento híbrido, apto a reunir as vantagens de ambas as vias.

Não obstante, a opção pela via administrativa com o passar do tempo, tende a evidenciar a natureza declaratória da usucapião, demonstrando as vantagens da regularização para o antigo proprietário, que não exerce posse no imóvel, porem ainda está vinculado aos 
deveres inerentes a propriedade o que, a nosso ver, conduzirá a uma possibilidade de consensualidade na usucapião, situação que atualmente, é quase impensável.

Nesse sentido, a possibilidade de optar pelo uso de uma das vias ou até mesmo pela conjugação delas poderá tornar a usucapião uma potente, acessível e efetiva ferramenta de regularização fundiária em consonância com o principio constitucional da função social da propriedade.

\section{BIBLIOGRAFIA.}

BRITO, Wagner de Mello. Cartórios Judiciais: suas práticas, ritos e impactos na marcha processual. 2013. Tese (Doutorado em Direito) - Programa de Pós-Graduação em Direito da Universidade Gama Filho. Rio de Janeiro.

CÂMARA, Alexandre Freitas. Lições de Direito Processual Civil. Volume III, 15 a Edição. Rio de Janeiro, Editora: Lumen Juris, 2009.

CAPPELLETTI, Mauro, GARTH, Bryant. Acesso à Justiça. Tradução de Ellen Gracie Northfleet. Porto Alegre: Ed. Sérgio Antonio Fabris, 1988.

CHALHUB, Melhim Namem, Propriedade imobiliária: função social e outros aspectos. Rio de Janeiro: Renovar, 2004.

DINIZ, Maria Helena. Sistemas de Registros de Imóveis, Rio de Janeiro: Saraiva, 2006.

DUARTE, Francisco Carlos. Direito e Justiça. In: XIX Conferência Nacional de Advogados aprova teses sobre Reforma da Justiça. Florianópolis, n. 3, 6 nov. 2005. Disponível em:<http://www.paranaonline.com.br/canal/direito-e-justica/news/147765>. Acesso em fevereiro de 2014.

GATTARI, Carlos Nicolás. Práctica notarial: donación dación em pago El notário, creador de derecho. 2 ed. Buenos Aires: Depalma, V. 4, 1996.

MEIRELLES, Hely Lopes. Direito Administrativo Brasileiro, São Paulo: Malheiros, 32a ed, 2006.

MELLO, Celso Antonio Bandeira de. Curso de Direito Administrativo. São Paulo: Malheiros, 2007.

PEREIRA, Caio Mário da Silva. Instituições de Direito Civil, vol. IV. 20 ed. Rio de Janeiro: Forense, 2003. 